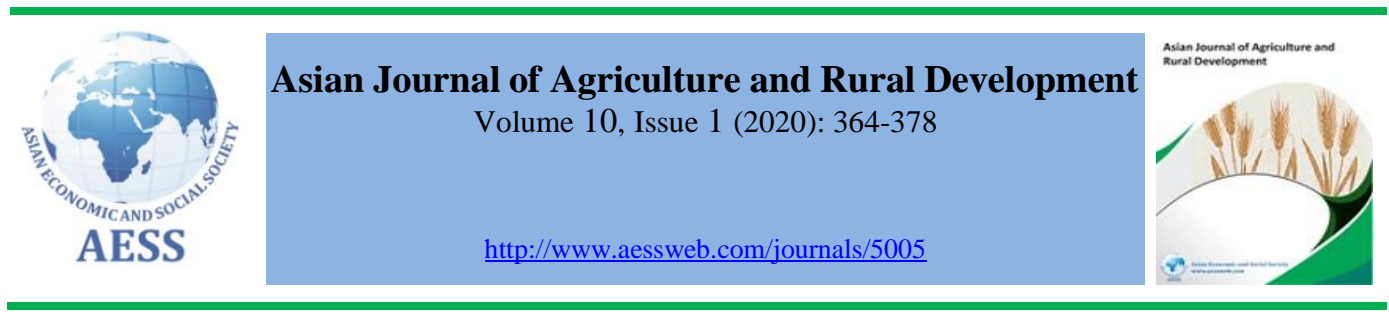

\title{
DEMAND ANALYSIS OF RICE IN NIGERIA: APPLICATION OF QUADRATIC ALMOST IDEAL DEMAND SYSTEM MODEL
}

iD Robert Ugochukwu Onyeneke ${ }^{\mathrm{a}}$

Chukwuemeka Chinonso

Emenekwe ${ }^{b}$

Mark Umunna Amadi a

Jane Onuabuchi

Munonye ${ }^{a}$

(D) Chukwudi Loveday

Njoku $^{\text {a }}$

Chibuzo Uzoma Izuogu ${ }^{a}$ a Department of Agriculture, Alex Ekwueme Federal University Ndufu-Alike, Ebonyi State, Nigeria

${ }^{\mathrm{b}}$ Department of Economics and Development Studies, Alex Ekwueme

Federal University Ndufu-Alike, Ebonyi State, Nigeria

- robertonyeneke@yahoo.com (Corresponding author)

\section{ARTICLE HISTORY:}

Received: 10-Mar-2020

Accepted: 11-May-2020

Online Available: 15-Jun2020

\section{Keywords:}

Imported rice,

Local rice,

Demand,

Elasticity,

LSMS-ISA,

Quadratic almost ideal

demand system

\begin{abstract}
The paper analyzed the demand for imported rice, local rice, maize, and other cereals in Nigeria. Using the second wave data of the Nigerian Living Standard Measurements Survey - Integrated Survey on Agriculture, it employed the Quadratic Almost Ideal Demand System model for empirical analysis. The result indicates that the imported and local rice are proved to be normal goods. However, imported rice is a luxury item while local rice is a necessity. The compensated and uncompensated own-price elasticities for imported and local rice are negative, indicating that an increase in ownprice will decrease its own-demand in line with the law of demand. The estimates of uncompensated cross-price elasticity show that imported rice and local rice are complements in Nigeria. Finally, the study represents an effort to disaggregate food demand analysis to obtain useful information on price and other factors determining the demand for specific foods.
\end{abstract}

\section{Contribution/ Originality}

This paper is an attempt to provide information on the demand for locally produced and imported rice in Nigeria and their views as either necessity and/or luxury commodities, across the different income quintiles, as well as in urban and rural areas across the country using the Quadratic Almost Ideal Demand System model.

DOI: $10.18488 /$ journal.1005/2020.10.1/1005.1.364.378

ISSN (P): 2304-1455/ISSN (E):2224-4433

How to cite: Robert Ugochukwu Onyeneke, Chukwuemeka Chinonso Emenekwe, Mark Umunna Amadi, Jane Onuabuchi Munonye, Chukwudi Loveday Njoku, and Chibuzo Uzoma Izuogu (2020). Demand analysis of rice in Nigeria: application of quadratic almost ideal demand system model. Asian Journal of Agriculture and Rural Development, 10(1), 364-378.

(C) 2020 Asian Economic and Social Society. All rights reserved. 


\section{INTRODUCTION}

Rice is an important staple food in Nigeria, with about 180 million people estimated to consume nearly several million tons of rice annually (Fakayode et al., 2010; Ojogho and Erhabor, 2011; Grow Africa, 2018). The production and consumption of rice, specifically the locally cultivated rice, has been taking place in Nigeria for a long time (Akinbile et al., 2008). Rice is important in Nigeria from different perspectives: first, based on the number of kilocalories it supplies per person and per day in Nigeria, the supply of milled rice from domestic production and imports has increased at a rapid rate and contests with cassava and yams as a principal staple (Johnson and Dorosh, 2015). The increased demand is about 5 million metric tons per annum; with annual domestic production increasing about 10 percent since the mid-1970s (Akande et al., 2007; Gyimah-Brempong and Kuku-Shittu, 2016).

The Nigerian government's agricultural policy, particularly on rice, seeks to achieve food security by increasing domestic production and export as well as enhancing the welfare of its citizens (Olayide et al., 2015). This was done to boost rice production to substitute rice imports (Ebuehi and Oyewole, 2007; Gyimah-Brempong and Kuku-Shittu, 2016). While rice has status as a staple, such programs, with their attendant import-substitution policies, could have unintended consequences on the welfare of the citizens if prices increase rapidly. While the current paper is not focused on government rice policy, understanding how government rice policy might affect households requires knowledge of the value attached to rice consumption as well as the elasticity of the demand for rice by the household.

Ojogho and Erhabor (2011) used a sample of 812 households in three Nigerian states and found that rice makes up the largest share of household total food expenditure, ranging from 21 and 28 percent for high-income urban households, while for rural low-income households it is about 24 and 28 percent. The second perspective is that rice demand in the country is very high and has led to increased import demand (Grow Africa, 2018; FAO, 2018).

The domestic production of rice increased to 4.3 million metric tons in 2006 from 2.7 million metric tons in 2001 (Emodi and Madukwe, 2008). This increase in demand could be attributed to population growth and changes in lifestyle. In other words, the demand for rice has outpaced its production in Nigeria. Between 2010 and 2012, rice supply was 5.1 million metric tons, at the same time the domestic output of milled rice was 2.7 million metric tons (Kuku-Shittu and Pradesha, 2013). Thus, imports have been filling the expanding gap between domestic production and consumption, with about 2.4 million metric tons imported (Kuku-Shittu and Pradesha, 2013). Nigerian rice consumption is also characterized by spatial differences across demographic and regional lines. There is a marked difference between the choice of rice-domestic or imported-by both urban and rural households. Imported rice constitutes about 72 percent of the rice consumed by the urban households, while for the rural households, it is about 33 percent (Johnson and Dorosh, 2015; Gyimah-Brempong and Kuku-Shittu, 2016). Urban households consider imported rice to be of higher quality (tastes, stonefree, and aesthetics). On the other hand, local rice is considered a cheaper alternative with sensorial attributes required for most local dishes (Bamidele et al., 2010).

Disaggregating rice consumption along Nigeria's six geopolitical zones shows per capita consumption ranging from lowest in the South-South to the highest in the North-West, with about 20kg and 39kg respectively (Johnson and Dorosh, 2015; Gyimah-Brempong and Kuku-Shittu, 2016). There are marked differences in rice preferences across regions in the country; in the north, the greater part of total rice demand is rice for flour, as opposed to grain, while in the southern part, there is a large preference for parboiled, and in particular, imported rice (Ogundele, 2014; Rutsaert et al., 2013). Varieties of rice cultivated across Nigeria include Oryza sativa and Oryza glaberrima (Oko et al., 2012). The increased demand for rice can be linked to a high rate of urbanization, higher incomes, lifestyle changes (UNEP, 2005; Nwanze et al., 2006; Demont et al., 2013). 
The demand for rice in Nigeria can be observed across settlements- rural and urban (Ogundele, 2014), while the government is making commitments to increase domestic rice production (Akande et al., 2007). Previous studies on rice demand and consumption in Nigeria have linked higher demand for imported rice by households with differences in quality (Bamidele et al., 2010; Gyimah-Brempong et al., 2012; Alfred and Adekayode, 2014). Currently, there are debates in the literature on food elasticities in developing countries. Additionally, elasticity estimates can differ based on the estimation methods used (Davis and Kilian, 2011; Menegaki, 2014). Therefore, proper policy decisions will benefit from new evidence of food commodities' elasticities at the country level, household location, and household income level. These results are very important for Nigeria, given the high demand for rice by households. Considering the many food policies, including import substitution, as well as food nutrition and security targets, it is important to obtain updated elasticity estimates to make proper policy decisions. This paper aims to provide new empirical evidence and further disaggregate rice elasticity estimates for Nigerian households. This paper adds to the existing literature on rice demand with a focus on Nigeria. The literature on demand for locally produced and imported rice in Nigeria is increasing. However, previous studies have not done enough to assess the preference of imported and locally produced rice and their view as either necessity and/or luxury commodities, across the different income quintiles, as well as in urban and rural areas of the most populous country in Africa. This has created a gap in consumer behaviour literature.

This paper is one of the first attempts in the Nigerian food context to estimate a disaggregated rice demand system based on the Quadratic Almost Ideal Demand System (QUAIDS) model of Banks et al. (1997). The analysis focuses on estimating the expenditure elasticities, uncompensated (or Marshallian) and compensated (or Hicksian) own- and cross-price elasticities for imported and local rice using a QUAIDS model.

\section{MODEL AND EMPIRICAL STRATEGY}

\subsection{The QUAIDS model}

The study of consumer demand for goods typically starts by estimating demand equations based on neoclassical consumer theory. Some popular demand systems in the literature include the Translog model, the Almost Ideal Demand System (AIDS), and the QUAIDS (Deaton and Muellbauer, 1980; Banks et al., 1997). The QUAIDS model allows for the estimation of demand elasticities, incorporating a quadratic income term that enables for observation of consumer behavior for certain goods such that a good could be a luxury at some point, but a necessity at another time.

The paper considers four food commodities: imported rice, local rice, maize, and other cereals in the model. For our purpose, we illustrate the model as the following non-linear system of equations for $i=1, \ldots, N$ goods, and $j=1, \ldots, N$ with budget shares $w i$, consumption budget $m$, and prices $p i$ :

$$
w_{i}=\alpha_{i}+\sum_{j=1}^{n} \gamma_{i j} \ln p_{j}+\beta_{i} \ln \left[\frac{m}{a(p)}\right]+\frac{\lambda_{i}}{b(p)}\left\{\ln \left[\frac{m}{P}\right]\right\}^{2}+\mu_{i}
$$

Where $\alpha_{i}, \beta_{i}, \gamma_{i j}$, and $\lambda_{i}$ are model parameters to be estimated; $\mathrm{m}$ is total expenditure; $p_{j}$ is the price of $\operatorname{good} j$; and $\ln (P)$ and $b(p)$ are translog and Cobb-Douglas price aggregator functions, respectively.

The translog price aggregator is written as:

$$
\ln (P)=\alpha_{0}+\sum_{i=1}^{n} \alpha_{i} \ln p_{i}+\frac{1}{2} \sum_{i=1}^{n} \sum_{j=1}^{n} \gamma_{i j} \ln p_{i} \ln p_{j},
$$

and the Cobb-Douglas price aggregator is written as: 


$$
b(p)=\prod_{i=1}^{n} P_{i}^{\beta_{i}}=\exp \left(\sum_{i} \beta_{i} \ln p_{i}\right)
$$

The paper follows the example of Banks et al. (1997) and Lakkakula et al. (2016) in setting the value of $\alpha_{0}$ the translog function. To reduce the number of estimated parameters and maximize household utility, three theoretical restrictions are imposed by the model, namely - adding up, homogeneity and symmetry:

A. Adding up indicates the sum of the budget shares equals 1:

$$
\sum_{i=1}^{n} \alpha_{i}=1 ; \sum_{i=1}^{n} \gamma_{i j}=0 ; \sum_{i=1}^{n} \beta_{i}=0 ; \sum_{i=1}^{n} \lambda_{i}=0
$$

B. Prediction of degree zero in prices and total expenditure:

$$
\sum_{j=1}^{n} \gamma_{i j}=0 ; \text { and }
$$

C. Slutsky symmetry indicates the substitution effect between commodities.

$$
\gamma_{i j}=\gamma_{j i} \text { for all } j \text { not equal to } i \text {. }
$$

The study includes household demographic factors in estimating the demand system the technique of Ray (1983) and Poi (2012).

\subsection{Demand elasticities}

As stated earlier, the QUAIDS model allows for the estimation of demand elasticities, which represents household demand response to changes in expenditure and prices. According to Attanasio et al. (2013), obtaining the model elasticities $\mu_{i}$ and $\mu_{i j}$ is done by differentiating the budget share equation (1) with respect to the $\log$ expenditure $(\operatorname{lnm})$ and $\log$ prices $\left(\ln p_{j}\right)$, respectively, as follows:

$$
\begin{aligned}
& \mu_{i}=\frac{\partial w_{i}}{\partial \ln m}=\beta_{i}+\frac{2 \lambda_{i}}{b(p)}\left\{\ln \left[\frac{m}{a(p)}\right]\right\} \\
& \mu_{i j}=\frac{\partial w_{i}}{\partial \ln p_{j}}=\gamma_{i j}-\mu_{i}\left(\alpha_{j}+\sum_{k} \gamma_{j k} \ln p_{k}\right)-\frac{\lambda_{i} \beta_{j}}{b(p)}\left\{\ln \left[\frac{m}{a(p)}\right]\right\}^{2}
\end{aligned}
$$

The budget elasticities, $e_{i}$ are derived as follows:

$$
e_{i}=\frac{\mu_{i}}{w_{j}}+1
$$

The uncompensated (Marshallian) price elasticities are given as:

$$
e_{i j}^{u}=\frac{\mu_{i j}}{w_{i}}-\delta_{i j}
$$

The compensated (Hicksian) price elasticities, which measure the substitution effects of price changes on the demand for other goods, are derived using the Slutsky's equation:

$$
e_{i j}^{c}=e_{i j}^{u}+e_{i} w_{j}
$$

The Quadratic Almost Ideal Demand model in this study is based on the Seemingly Unrelated Regression (SUR). Regression coefficients are obtained using the Iterative Feasible Generalized Least Squares, while the estimation process was conducted in Stata 16 using the QUAIDS command (Poi, 2012). 


\subsection{The data}

The study used data on household consumption expenditure from the Living Standards Measurement Survey - Integrated Survey on Agriculture (LSMS-ISA) dataset, which was the survey resulting from a partnership of the Nigeria National Bureau of Statistics (NBS) with the Federal Ministry of Agriculture and Rural Development (FMA\&RD), the National Food Reserve Agency (NFRA), Bill and Melinda Gates Foundation (BMGF) and World Bank (National Bureau of Statistics 2014; 20122013). This data is representative at the national, rural, and urban levels, and of the six geopolitical zones of Nigeria. The paper used the second (collected September 2012 to April 2013) wave of the survey data, focusing on the household questionnaire and specifically on household imported rice, local rice and other cereals (maize, millet, and sorghum) consumption and household demographic characteristics. We included other cereals in our analysis to further track whether other cereals are close substitutes or complement with imported rice or local rice. Such a result will guide policymaking towards rice production and consumption in Nigeria. The study chose the second wave of the LSMS-ISA because it was collected at a time when the implementation of the Agricultural Transformation Agenda of the country has started in earnest. The Agricultural Transformation Agenda was implemented in Nigeria between 2011 and 2015.

\subsection{Treatment of prices and unit values}

Economic literature uses unit values to approximate prices, calculated by dividing expenditure by the quantity of the purchased goods. There are criticisms regarding the use of unit values for price approximations such as quality effects and measurement error (Deaton, 1988; Gibson and Rozelle, 2005). However, its use remains popular in empirical studies for a lack of better alternatives (Attanasio et al., 2013). In this study, we also use unit values to approximate the prices of the goods of interest.

\subsection{Treatment of missing expenditure data and non-purchased foods}

Most surveys do not report expenditure data for individual commodities, and the second wave of the LSMS-ISA is no exception. The potential sources of zero expenditure for individual commodities include permanent zero consumption and zero consumption at the time of the survey. In the LSMSISA dataset, there are specific questions on consumption and expenditure during the last seven days; most households may not have purchased, but consumed during the reference week, while on the other hand, most households may have purchased food for consumption at a later time. These cases lead to some households reporting zero purchase or consumption even where there is positive quantity purchase or consumption. In the second wave of the Nigeria LSMS-ISA dataset, 4,986 households completed the questionnaires. For this study, we drop 1,719 households who reported zero consumption or expenditure for all food items, including rice, under the cereals section of the survey questionnaire. The study continued with households that consumed at least one cereal food item. Ringstad and Loyland (2011) note that zero observations for any food item could be a result of the censorship problem which affects error term distributions. While using the QUAIDS model, they argue that the impact of the share of zero observations is insignificant with the inclusion of demographic variables, since they matter more. Hence, we include household demographic variables and this reinforces our use of the QUAIDS model to estimate the rice demand in Nigeria.

The household expenditure on each good, which is used to obtain total household cereals expenditure, was calculated. Furthermore, for households reporting monetary values for food purchases, we consider those monetary values. While for households with home-produced goods without reported monetary values, following Attanasio et al. (2013), we use state-level or region-level mean unit values to multiply home-produced quantities to obtain total monetary values for food consumption. 


\section{RESULTS AND DISCUSSION}

\subsection{Descriptive statistics}

In Table 1, we present the descriptive statistics of our variables of interest. The results show that approximately 47 percent of household cereals expenditure is allocated to foreign rice and about 29 percent is allocated to local rice. The weekly average household cereals expenditure is $\$ 1,333$ during the period under study. The average household has 6 members, while the average household head's age is 49 years. About 84 percent of households are headed by males, while half of the household heads in our sample have a formal education. Additionally, about 67 percent of the households in our sample are located in the rural areas, while most households are located in the North-West and SouthWest regions and the least is in the North-East region.

Table 1: Summary statistics of variables

\begin{tabular}{lcc}
\hline Variable & Mean & Std. Dev. \\
\hline Budget Share of Imported Rice & 0.472 & 0.467 \\
Budget Share of Local Rice & 0.292 & 0.374 \\
Budget Share of Maize & 0.072 & 0.168 \\
Budget Share of Other Cereals & 0.164 & 0.256 \\
Log Price of Imported Rice & 4.845 & 1.030 \\
Log Price of Local Rice & 4.034 & 1.087 \\
Log Price of Maize & 2.596 & 1.109 \\
Log Price of Other Cereals & 2.83 & 1.193 \\
Household Cereals Budget (Expenditure) & 1333.59 & 1656.843 \\
Log Household Income & 11.403 & 0.757 \\
Household Size & 6.499 & 3.231 \\
Household Settlement (1 = Rural) & 0.667 & 0.471 \\
Male-Headed Household & 0.843 & 0.364 \\
Age of Head Household & 49.356 & 16.827 \\
Formal Education of Head of Household & 0.551 & 0.497 \\
Marital Status (1 = Married) & 0.796 & 0.403 \\
South-East Region (1 = South-East) & 0.169 & 0.375 \\
South-West Region (1 = South-West) & 0.188 & 0.390 \\
South-South Region (1 = South-South) & 0.170 & 0.376 \\
North-Central Region (1 = North-Central) & 0.178 & 0.382 \\
North-West Region (1 = North-West) & 0.188 & 0.390 \\
North-East Region (1 = North-East) & 0.151 & 0.358 \\
\hline
\end{tabular}

\subsection{Demographic variables test}

Demographic variables are important in consumer demand analysis by enabling a better understanding of consumer behavior. The Wald test to check the necessity and significance of demographic variables in the QUAIDS model was carried out. Specifically, the paper tested for the significance of included demographic variables (Poi, 2012).

The paper further checked for the appropriateness of the QUAIDS model for this study by testing the null hypothesis that all lambda coefficients equal to zero. Failure to reject the null hypothesis implies the appropriateness of the AIDS model. Rejection, on the other hand, implies we use the QUAIDS model for this study (Gostkowski, 2018). The Wald test statistics for the lambda coefficients and demographic coefficients are all significant, indicating the appropriateness of the QUAIDS model (Larochelle et al., 2017). 


\subsection{Elasticity results}

The estimated coefficients of the QUAIDS model are difficult to interpret due to no direct economic interpretation; however, we report them in Table A1 in the Appendix. These coefficients are used to obtain the associated price and expenditure elasticities which are of policy relevance (Curtis and Stanley, 2015). To describe the results of the overall demand for rice in Nigeria, the study estimated the expenditure and own-price elasticity to ascertain Nigerian households' responsiveness to price and income changes. The paper also probed the cross-price elasticity to determine if imported rice and local rice are complements or substitutes. Furthermore, the study extended rice demand elasticity analysis by income quintiles, urban and rural locations.

Table 2 reports the results of expenditure elasticities and compensated and uncompensated own-price elasticities of the food items at the country level. From the results, imported rice has an expenditure elasticity of 1.137 , indicating that a one percent increase in total cereals expenditure will lead to a one percent decrease in foreign rice spending. On the other hand, the expenditure elasticity of local rice is less than one, 0.693 . This indicates that a one percent increase in total cereals expenditure will lead to a less than one percent increase in local rice spending. These results show that foreign rice is a luxury while local rice is a necessity. Similarly, maize is shown to be a necessity item in our results, while the other cereals (including millet and sorghum) are luxury food items. Furthermore, at the country level, the uncompensated and compensated own-price elasticities are negative for all food items. The study finds similar results when we disaggregate country-level estimates across income quintiles; these results are reported in Table A2 in the appendix.

The paper expected dissimilarities or heterogeneity in household consumption patterns across household location and income quintiles; hence the analysis was extended by disaggregating estimates by household settlement: rural and urban areas and income quintiles in Tables A3 through A5 in the appendix. In Table A3, we report the expenditure elasticities, uncompensated and compensated own-price elasticities disaggregated by income quintiles for urban and rural households. In Tables A4 and A5, the paper reported the expenditure elasticities, uncompensated and compensated own-price and cross-price elasticities for rural and urban households, respectively.

Part A of Table A3 reports the expenditure elasticity, while Part B and Part C report compensated and uncompensated own-price elasticity estimates. For households in rural and urban areas, imported rice has an expenditure elasticity of 1.178 and 1.093, respectively. These results are in line with the country level results, indicating that a one percent increase in total cereals expenditure will lead to more than one percent decrease in foreign rice spending. The estimates further show expenditure elasticities for imported rice ranging from 1.083 to 1.337 for the lowest to the highest income quintiles in rural and urban areas. These results imply that foreign rice is a luxury food item in Nigeria. Local rice expenditure elasticity for rural and urban areas is 0.740 and 0.515 , respectively. When disaggregated income quintiles, the expenditure elasticities range from 0.326 to 0.749 across rural and urban areas. These results are similar to the country level results, indicating that a one percent increase in total cereals expenditure will lead to a one percent increase in local rice spending.

Table 2: Results of elasticity of QUAIDS model

\begin{tabular}{lcccc}
\hline & & Price & & \\
& Imported Rice & Local Rice & Maize & Other Cereals \\
\hline Budget Elasticity & 1.137 & 0.693 & 0.936 & 1.180 \\
& $(0.012)$ & $(0.019)$ & $(0.045)$ & $(0.022)$ \\
Compensated Elasticity & & & & \\
Im & -0.233 & 0.065 & 0.055 & 0.113 \\
Imported Rice & $(0.011)$ & $(0.008)$ & $(0.006)$ & $(0.008)$ \\
& 0.111 & -0.193 & 0.023 & 0.059 \\
\hline
\end{tabular}




\begin{tabular}{|c|c|c|c|c|c|}
\hline & & $(0.013)$ & $(0.020)$ & $(0.008)$ & $(0.012)$ \\
\hline & Maize & 0.350 & 0.112 & -0.397 & -0.065 \\
\hline & & $(0.035)$ & $(0.035)$ & $(0.038)$ & $(0.030)$ \\
\hline & Other Cereals & 0.320 & 0.106 & -0.026 & -0.401 \\
\hline & & $(0.023)$ & $(0.021)$ & $(0.013)$ & $(0.033)$ \\
\hline Un & npensated Elasti & & & & \\
\hline & Imported Rice & -0.770 & -0.267 & -0.027 & -0.074 \\
\hline & & $(0.012)$ & $(0.008)$ & $(0.006)$ & $(0.008)$ \\
\hline Z्్ & Local Rice & -0.216 & -0.395 & -0.026 & -0.055 \\
\hline 胥 & & $(0.017)$ & $(0.022)$ & $(0.008)$ & $(0.011)$ \\
\hline ص̊ & Maize & -0.092 & -0.162 & -0.464 & -0.218 \\
\hline & & $(0.038)$ & $(0.035)$ & $(0.039)$ & $(0.030)$ \\
\hline & Other Cereals & -0.237 & -0.238 & -0.111 & -0.594 \\
\hline & & $(0.025)$ & $(0.021)$ & $(0.013)$ & $(0.034)$ \\
\hline
\end{tabular}

Note: Standard errors in parenthesis

The country-level estimates show that the expenditure elasticities are positive and significant, indicating that both imported and local rice are normal goods. Furthermore, two expenditure commodities are necessities, with elasticities less than one, namely local rice and maize. The other expenditure commodities are luxuries, with expenditure elasticities above one. These luxuries are imported rice and 'other' cereals group which include millet and guinea corn/sorghum. The results further show that expenditure on imported rice will grow in line with household expenditures, while expenditure on local rice will grow slower than household expenditure. Put differently, while the Naira amount spent by the household on rice will increase for both types of rice, the percentage expenditure on imported rice will rise with household expenditure, while the percentage expenditure on local rice will decrease, ceteris paribus. These estimates remain consistent when we further consider household income classifications. The results also show that for all income quintiles, in both rural and urban areas, imported rice is a luxury commodity while local rice is a necessity. The results are comparable with Gyimah-Brempong and Kuku-Shittu (2016), who used an AIDS model and find that both types of rice have positive and significant expenditure elasticities nationally and across urban and rural areas, indicating that both types of rice are necessities, with expenditure elasticities below one. Their result for imported rice differs from our results. Furthermore, our results are related to studies that used the AIDS model and found significantly positive expenditure elasticities for rice in Nigeria (Ojogho and Erhabor, 2011; Makama et al., 2017).

The uncompensated and compensated own-price elasticities are reported in Tables 2, A4, and A5. The own-price elasticities are the diagonal elements in the matrices. At the country-level, as expected, all the uncompensated and compensated own-price elasticities are negative for imported rice for all income quintiles, in both rural and urban areas, indicating that an increase in the own-price of imported rice will result in a decrease in its demand (Kuku-Shittu and Pradesha, 2013). For local rice, uncompensated and compensated own-price elasticity is negative for all rural and urban areas, as well as all income quintiles in rural areas. While results remain consistent, conversely, local rice is estimated to be a Giffen good for households in the second- and third-income quintile, in both urban and rural areas, with positive uncompensated and compensated own-price elasticities of demand.

The uncompensated and compensated cross-price elasticities are reported in Tables 2, A4, and A5. Cross-price elasticities are the off-diagonal elements. Cross-price elasticities of each food commodity with respect to other food commodities' prices are observed by column. The negative uncompensated cross-price elasticities indicate that foreign rice is a complement to local rice. Similarly, local rice is a complement to foreign rice. Maize and other cereals are also complemented to imported rice and local rice. All the cross-price elasticities of imported rice are less than one in absolute terms, with respect to the prices of other commodities. This result indicates that a percentage increase in the prices of most foreign rice complements would decrease the quantity demanded rice by less than 1 
percent. The same result applies to locally produced rice and other food commodities at the country level and rural and urban areas.

Compensated cross-price elasticities consider the substitution effect of a price change. Estimates here show that all food commodities are potential substitutes for foreign rice. Similarly, all commodities are potential substitutes for local rice. The paper noted that the elasticity of foreign rice with respect to the price of local rice quite inelastic. In other words, a percentage increase in quantity demanded foreign rice is not greater than the percentage change in the price of the local rice. The overall findings are in line with Gyimah-Brempong and Kuku-Shittu (2016) and Kuku-Shittu and Pradesha (2013) who study rice demand in Nigeria using LA-AIDS model and the 2010 to 2011 wave of the LSMSISA dataset.

In general, individual food commodities respond less to changes in other commodities' prices than their own. While findings from compensated cross-price elasticities are small, we find that imported rice and local rice have negative cross-price elasticities, and complement according to uncompensated cross-price elasticity estimates, indicating that an increase in the price of one will result in a decrease in the consumption of the other. This finding is similar to Gyimah-Brempong and Kuku-Shittu (2016) who found that both types of rice are complements, with cross elasticity of 0.003. Similarly, Demont et al. (2013) studied rice demand in Senegal and also found that local and imported rice is characterized by low substitutability. Compensated cross-price elasticity estimates between rice and other food commodities are small and mostly insignificant.

\section{CONCLUSION}

Our tests indicated that the QUAIDS model was empirically appropriate for analyzing household budgeting decisions among Nigerian households. Expenditure and price elasticities were estimated for four food commodities. These four food commodities include imported rice, local rice, maize, and other cereals (millet and guinea corn/sorghum). We incorporate household demographic variables using the demographic scaling approach of Ray (1983) and Poi (2012). Furthermore, we compare expenditure and price elasticities across locations (rural-urban) and income quintiles to show the nature and structure of rice demand in Nigeria.

The paper found that all food commodities are normal goods, with positive expenditure elasticities. However, imported rice and other cereals are luxury foods, while local rice and maize are necessities. Furthermore, we find significant price effects for all food commodities. Also, the paper found very low cross-price elasticities, which suggests limited substitutability between imported rice and local rice. The paper also found higher expenditure and own-price elasticities for rural compared with urban households. The results also show food rice demand for poorer households has higher expenditure and own-price elasticities than richer households.

In general, the expenditure elasticity for rice is positive and high indicating that demand for rice rises as household income rises. Imported rice has higher expenditure elasticity than locally produced rice across urban and rural areas, and across all household income quintiles, indicating that it is the more preferred rice in Nigeria. This paper provides new empirical elasticities estimates using the QUAIDS model and the 2012 to 2013 wave of the LSMS-ISA dataset. Finally, the study represents a timely effort to disaggregate food demand analysis to obtain useful information on price and other factors determining the demand for specific foods. Policymaking and marketing decision making will benefit from studies such as ours since such decisions benefit from better knowledge of food and householdspecific responses that help to carry out proper market segmentation. 


\begin{abstract}
Funding: This study did not receive any specific financial support.
Competing Interests: The authors declared that they have no conflict of interests.

Contributors/Acknowledgement: The authors are grateful to the National Bureau of Statistics and their partners (Federal Ministry of Agriculture and Rural Development, the National Food Reserve Agency, Bill and Melinda Gates Foundation and World Bank) for the LSMS-ISA second wave dataset.

Views and opinions expressed in this study are the views and opinions of the authors, Asian Journal of Agriculture and Rural Development shall not be responsible or answerable for any loss, damage or liability, etc. caused in relation to/arising out of the use of the content.
\end{abstract}

\title{
References
}

Akande, T., Cisse, Y., \& Kormawa, P. (2007). Streamlining policies for exchanging rice production in Africa: past experiences, lessons learnt and the way forward. African Crop Science Journal, 15(4), 223-235

Akinbile, L. A., Akinwale, J. A., \& Ashimolowo, O. R. (2008). Determinants of productivity level among rice farmers in Obafemi-owode local government area of Ogun State, Nigeria. Journal of New Seeds, 8(4), 79-90. doi.org/10.1300/j153v08n04_06.

Alfred, S. D., \& Adekayode, A. B. (2014). Consumers' attitude towards local rice production in Ondo State, Nigeria. Journal of Agricultural Extension and Rural Development, 6(7), 242-248. doi.org/10.5897/jaerd11.014.

Attanasio, O., Di Maro, V., Lechene, V., \& Phillips, D. (2013). Welfare consequences of food prices increases: Evidence from rural Mexico. Journal of Development Economics, 104, 136-151. doi.org/10.1016/j.jdeveco.2013.03.009.

Bamidele, F. S., Abayomi, O. O., \& Esther, O. A. (2010). Economic analysis of rice consumption patterns in Nigeria. Journal of Agricultural Science and Technology, 12, 1-11. doi.org/10.4314/bja.v4i1.41928.

Banks, J., Blundell, R., \& Lewbel, A. (1997). Quadratic Engel curves and consumer demand. Review of Economics and Statistics, 79, 527-539. doi.org/10.1162/003465397557015.

Curtis, J., \& Stanley, B. (2015). Analysing residential energy demand: an error correction demand system approach for Ireland. Dublin: The Economic \& Social Research Institute Working Paper No. 505.

Davis, L. W., \& Kilian, L. (2011). Estimating the effect of a gasoline tax on carbon emissions. Journal of Applied Econometrics, 26(7), 1187-1214. doi.org/10.3386/w14685.

Deaton, A. (1988). Quality, quantity, and spatial variation of price. American Economic Review, $78(3), 418-430$.

Deaton, A., \& Muellbauer, J. (1980). An almost ideal demand system. American Economic Review, 70, 312-326. doi.org/10.4337/9781781001295.00014.

Demont, M., Rutsaert, P., Ndour, M., \& Verbeke, W. (2013). Reversing urban bias in African rice markets: evidence from Senegal. World Development, 45, 63-74. doi.org/10.1016/j.worlddev.2012.11.011.

Ebuehi, O. A., \& Oyewole, A. C. (2007). Effects of cooking and soaking on physical characteristics, nutrient composition and sensory evaluation of indigenous and foreign rice varieties in Nigeria. African Journal of Biotechnology, 6(8), 1016-1020. doi.org/10.1108/00346650810847972.

Emodi, I. A., \& Madukwe, M. C. (2008). A review of policies, acts and initiatives in rice innovation system in Nigeria. Journal of Agricultural Extension, 12(2), 76-83. doi.org/10.4314/jae.v12i2.47052.

Fakayode, S. B., Omotesho, O. A., \& Omoniwa, A. E. (2010). Economic analysis of rice consumption patterns in Nigeria. Journal of Agricultural Science and Technology, 12, 135-144.

FAO (2018). FAO in Nigeria: Nigeria at a Glance. Retrieved from food and agriculture organization of the United Nations: www.fao.org/nigeria/fao-in-nigeria/nigeria-at-a-glance/en.

Gibson, J., \& Rozelle, S. (2005). Prices and unit values in poverty measurement and tax reform analysis. The World Bank Economic Review, 19(1), 69-97.

Grow Africa (2018). ECOWAS rice fact book. Johannesburg: Grow Africa Secretariat. 
Gostkowski, M. (2018). Elasticity of consumer demand: estimation using a quadratic almost ideal demand system. Econometrics. Ekonometria Advances in Applied Data Analysis, 22(1), 6878

Gyimah-Brempong, K., Dorosh, P., Pradesha, A., \& Ajibola, A. (2012). Informing Nigeria's agricultural transformation agenda with policy analysis and research evidence. Paper presented at NSSP National Conference Held in Abuja, 13 ${ }^{\text {th }}-14^{\text {th }}$ November 2012.

Gyimah-Brempong, K., \& Kuku-Shittu, O. (2016). Evolution of Rice Consumption and Demand Patterns. In: K Gyimah-Brempong, M Johnson \& $\mathrm{H}$ Takeshima, The Nigerian Rice Economy: Policy Options for Transforming Production, Marketing, and Trade (pp. 21-50). Philadelphia: University of Pennsylvania Press.

Johnson, M., \& Dorosh, P. (2015). Optimal tariffs with smuggling: a spatial analysis of Nigerian rice policy options. International Food Policy Research Institute (IFPRI) Discussion Paper 01493.

Kuku-Shittu, O., \& Pradesha, A. (2013). An econometric analysis of rice demand in Nigeria. Paper presented at the $18^{\text {th }}$ Annual Conference on Econometric Analysis and Policy Challenges in Africa. doi.org/10.4314/bja.v4i1.41928.

Lakkakula, P., Schmitz, A., \& Ripplinger, D. (2016). U.S. sweetener demand analysis: A QUAIDS model application. Journal of Agricultural and Resource Economics, 41(3), 533-548.

Larochelle, C., Katungi, E., \& Cheng, Z. (2017). Pulse consumption and demand by different population subgroups in Uganda and Tanzania. Uganda: International Center for Tropical Agriculture (CIAT); Pan-African Bean Research Alliance (PABRA).

Makama, S. A., Ilu, I. Y., Suleiman, N. J., Isiaku, S., \& Isah, M. A. (2017). Demand analysis of rice in Nigeria. Nigerian Journal of Agricultural Extension, 18(3), 70-75.

Menegaki, A. N. (2014). On energy consumption and GDP studies: a meta-analysis of the last two decades. Renewable and Sustainable Energy Reviews, 29, 31-36.

Nwanze, K. F., Mohapatra, S., Kormawa, P., Keya, S., \& Bruce-Oliver, S. (2006). Rice Development in sub-Saharan Africa. Journal of the Science of Food and Agriculture, 86(5), 675-677.

Ogundele, O. (2014). Factors influencing consumers' preference for local rice in Nigeria. African Journal of Marketing Management, 6(4), 49-55. doi.org/10.5897/ajmm2011.048.

Ojogho, O., \& Erhabor, P. O. (2011). Rice demand pattern and its intervening factors in Nigeria. International Journal of Agricultural Research, 6(11), 769-779. doi.org/10.3923/ijar.2011.769.779.

Oko, A. O., Ubi, B. E., \& Efisue, A. A. (2012). A comparative study on local and newly introduced rice varieties in Ebonyi state of Nigeria based on selected agronomic characteristics. International Journal of Agriculture and Forestry, 2(1), 11-17.

Olayide, O. E., Tetteh, I. K., \& Popoola, L. (2015). Trends and policy correlate of agricultural production and agricultural sustainability outcomes in Ghana and Nigeria. Journal of Sustainable Development, 8(9), 71-78. doi.org/10.5539/jsd.v8n9p71.

Poi, B. P. (2012). Easy demand-system estimation with QUAIDS. The Stata Journal, 12(3), 433-446.

Ray, R. (1983). Measuring the costs of children: an alternative approach. Journal of Public Economics, 22(1), 89-102.

Ringstad, V., \& Loyland, K. (2011). Performing arts and cinema demand: some evidence of Linder's disease. Applied Economics Quarterly, 57(4), 255-284. doi.org/10.3790/aeq.57.4.255.

Rutsaert, P., Demont, M., \& Verbeke, W. (2013). Consumer Preferences for Rice in Africa. In M Wopereis, M Wopereis, D Johnson, E Tollens and A. Jalloh (Eds.), Realizing Africa's Rice Promise (pp. 294-302). Wallingford, UK: CAB International.

UNEP (2005). Integrated assessment of the impact of trade liberlaization: a country study on the Nigerian rice sector. Geneva: United Nations Environmental Programme (UNEP). 


\section{Appendix}

\section{Appendix A: Demand system estimation results}

Table A1: Food budget equation parameter estimates

\begin{tabular}{|c|c|c|c|c|}
\hline & Imported Rice & Local Rice & Maize & Other Cereals \\
\hline \multirow[t]{2}{*}{ constant } & $0.824 * * *$ & $-2.791 * * *$ & $1.290 * * *$ & $1.677 * * *$ \\
\hline & $(-0.184)$ & $(-0.163)$ & $(-0.144)$ & $(-0.168)$ \\
\hline \multirow[t]{2}{*}{ Expenditures } & 0.007 & $-0.123 * * *$ & $0.068 * * *$ & $0.048 * * *$ \\
\hline & $(-0.009)$ & $(-0.009)$ & $(-0.007)$ & $(-0.008)$ \\
\hline \multirow[t]{2}{*}{ Quadratic Expenditures } & -0.001 & -0.0004 & $0.001 * * *$ & $0.001 * * *$ \\
\hline & $(0.000)$ & $(0.000)$ & $(0.000)$ & $(0.000)$ \\
\hline \multirow[t]{2}{*}{ Price_Imported Rice } & $0.200 * * *$ & $-0.150 * * *$ & $-0.0331 * * *$ & $-0.0172 *$ \\
\hline & $(-0.009)$ & $(-0.019)$ & $(-0.009)$ & $(-0.010)$ \\
\hline \multirow[t]{2}{*}{ Price_Local Rice } & & $0.452 * * *$ & $-0.132 * * *$ & $-0.171 * * *$ \\
\hline & & $(-0.035)$ & $(-0.017)$ & $(-0.021)$ \\
\hline \multirow[t]{2}{*}{ Price_Maize } & & & $0.117 * * *$ & $0.0485 * * *$ \\
\hline & & & $(-0.015)$ & $(-0.007)$ \\
\hline \multirow[t]{2}{*}{ Price_Other Cereals } & & & & $0.139 * * *$ \\
\hline & & & & $(-0.018)$ \\
\hline \multirow[t]{2}{*}{ Household Size } & $0.000196 * * *$ & $-0.000361 * * *$ & $-8.59 \mathrm{e}-05^{*}$ & $0.0002 * * *$ \\
\hline & $(-7.56 \mathrm{e}-05)$ & $(-7.27 \mathrm{e}-05)$ & $(-4.43 e-05)$ & $(-5.19 \mathrm{e}-05)$ \\
\hline \multirow[t]{2}{*}{ Rural } & $0.00347 * * *$ & $-0.00164 * * *$ & -0.000202 & $-0.00163 * * *$ \\
\hline & $(-0.001)$ & $(0.000)$ & $(0.000)$ & $(0.000)$ \\
\hline \multirow{2}{*}{ Male-headed Household } & $0.00172 *$ & $-0.00158 * *$ & 0.000307 & -0.000449 \\
\hline & $(-0.001)$ & $(-0.001)$ & $(0.000)$ & $(0.000)$ \\
\hline \multirow[t]{2}{*}{ Age of Head } & $1.58 \mathrm{e}-07$ & $2.19 \mathrm{e}-07$ & $-1.77 \mathrm{e}-07$ & $-1.99 \mathrm{e}-07$ \\
\hline & $(-1.33 \mathrm{e}-05)$ & $(-1.19 \mathrm{e}-05)$ & $(-7.80 e-06)$ & $(-8.69 \mathrm{e}-06)$ \\
\hline \multirow[t]{2}{*}{ Any Education } & $-0.00350 * * *$ & $0.002 * * *$ & 0.0002 & $0.002 * * *$ \\
\hline & $(0.000)$ & $(0.000)$ & $(0.000)$ & $(0.000)$ \\
\hline \multirow[t]{2}{*}{ Marital Status } & 0.00122 & -0.000336 & -0.000421 & -0.000468 \\
\hline & $(-0.001)$ & $(-0.001)$ & $(0.000)$ & $(0.000)$ \\
\hline \multirow[t]{2}{*}{ Household Income } & $-0.00198 * * *$ & $-0.000578 *$ & $0.000736 * * *$ & $0.00182 * * *$ \\
\hline & $(0.000)$ & $(0.000)$ & $(0.000)$ & $(0.000)$ \\
\hline \multirow[t]{2}{*}{ South-West } & $-0.00696^{* * *}$ & $0.00515 * * *$ & -0.000238 & $0.00205 * * *$ \\
\hline & $(-0.001)$ & $(-0.002)$ & $(0.000)$ & $(-0.001)$ \\
\hline \multirow[t]{2}{*}{ South-South } & $-0.0174 * * *$ & $0.0190 * * *$ & $0.00224 * *$ & $-0.00378 * * *$ \\
\hline & $(-0.002)$ & $(-0.002)$ & $(-0.001)$ & $(-0.001)$ \\
\hline \multirow[t]{2}{*}{ North-Central } & $-0.00760 * * *$ & $0.0169 * * *$ & $-0.00243 * *$ & $-0.00682 * * *$ \\
\hline & $(-0.002)$ & $(-0.002)$ & $(-0.001)$ & $(-0.001)$ \\
\hline \multirow[t]{2}{*}{ North-West } & $-0.00798 * * *$ & $0.0218 * * *$ & $-0.00263 * * *$ & $-0.0112 * * *$ \\
\hline & $(-0.002)$ & $(-0.002)$ & $(-0.001)$ & $(-0.001)$ \\
\hline \multirow[t]{2}{*}{ North-East } & $-0.00684 * * *$ & $0.0196 * * *$ & $-0.00166^{*}$ & $-0.0111 * * *$ \\
\hline & $(-0.002)$ & $(-0.002)$ & $(-0.001)$ & $(-0.001)$ \\
\hline Observations & 3,266 & 3,266 & 3,266 & 3,266 \\
\hline
\end{tabular}

Robust standard errors in parentheses $* * * \mathrm{p}<0.01$, ** $\mathrm{p}<0.05, * \mathrm{p}<0.1$ 
Table A2: Country-level expenditure and own-price elasticity estimates by income quintile

\begin{tabular}{|c|c|c|c|c|c|c|}
\hline \multicolumn{7}{|c|}{ Part A: QUAIDS Expenditure Elasticities by Income Quintile } \\
\hline & \multirow{2}{*}{ All } & \multicolumn{5}{|c|}{ Quintile } \\
\hline & & Q1 & Q2 & Q3 & Q4 & Q5 \\
\hline Imported Rice & 1.137 & 1.111 & 1.117 & 1.124 & 1.178 & 1.227 \\
\hline Local Rice & 0.693 & 0.695 & 0.661 & 0.653 & 0.713 & 0.730 \\
\hline Maize & 0.936 & 0.679 & 0.921 & 0.934 & 0.972 & 1.007 \\
\hline Other Cereals & 1.180 & 1.820 & 1.445 & 1.206 & 1.112 & 1.089 \\
\hline \multicolumn{7}{|c|}{ Part B: QUAIDS Compensated Own-Price Elasticities by Income Quintile } \\
\hline Imported Rice & -0.233 & -0.158 & -0.184 & -0.214 & -0.246 & -0.174 \\
\hline Local Rice & -0.193 & -0.240 & -0.211 & -0.169 & -0.184 & -0.151 \\
\hline Maize & -0.397 & -0.002 & -0.486 & -0.465 & -0.448 & -0.358 \\
\hline Other Cereals & -0.401 & 0.834 & 0.039 & -0.374 & -0.448 & -0.426 \\
\hline \multicolumn{7}{|c|}{ Part C: QUAIDS Uncompensated Own-Price Elasticities by Income Quintile } \\
\hline Imported Rice & -0.770 & -0.866 & -0.831 & -0.800 & -0.659 & -0.496 \\
\hline Local Rice & -0.395 & -0.168 & -0.389 & -0.337 & -0.404 & -0.392 \\
\hline Maize & -0.464 & 0.183 & -0.561 & -0.539 & -0.532 & -0.440 \\
\hline Other Cereals & -0.594 & -1.165 & -0.060 & -0.546 & -0.730 & -0.781 \\
\hline
\end{tabular}

Note: Country-level expenditure, uncompensated, compensated own-price elasticity for imported and local rice and other cereals, using Nigeria LSMS-ISA survey data (2012-2013).

Source: Own Estimates

Table A3: Expenditure and own-price elasticity estimates by settlement and income quintile

\begin{tabular}{|c|c|c|c|c|c|c|c|c|c|c|c|c|}
\hline & \multicolumn{6}{|c|}{ Rural } & \multicolumn{6}{|c|}{ Urban } \\
\hline & \multirow{2}{*}{ All } & \multicolumn{5}{|c|}{ Quintile } & \multirow{2}{*}{ All } & \multicolumn{5}{|c|}{ Quintile } \\
\hline & & Q1 & Q2 & Q3 & Q4 & Q5 & & Q1 & Q2 & Q3 & Q4 & Q5 \\
\hline montod Dich & & 1.128 & 1.142 & 1.171 & 1.261 & 1.337 & & 1.089 & 1.087 & 1.083 & 1.102 & 1.124 \\
\hline $0 \mathrm{c}$ & & 0.747 & 0.729 & 0.729 & 0.747 & 0.749 & & 0.506 & 0.342 & 0.326 & 0.589 & \\
\hline & & 07 & 0.943 & 0.955 & & & & & 38 & 27 & & \\
\hline & & 1.6 & 1.354 & 1.150 & & & & & 789 & .469 & 49 & \\
\hline \multicolumn{13}{|c|}{ art B: QUAIDS compensated own-price elasticities by urban-rural settlement and income quintile } \\
\hline & & & & & & & & & & -0.0 & & $F_{-1}$ \\
\hline & & & -0.2 & -0.2 & & -0 . & -0. & -0. & 0.154 & 0.186 & & $-0.1+3<$ \\
\hline & & & -0.529 & -0.5 & & $x^{2}+2$ & 0 & 9 & -0.303 & -0.12 & & -0.39 \\
\hline 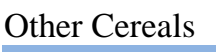 & -0.424 & 0.528 & -0.070 & -0.412 & ו & & & 2.403 & 0.477 & -0.077 & & -0.45 \\
\hline \multicolumn{13}{|c|}{ art C: QUAIDS uncompensated own-price elasticities by urban-rural settlement and income quintile } \\
\hline & & & & & & & & & & & & 0.70 \\
\hline & & & & & & & & & 0.107 & 0.143 & & -0.28 \\
\hline & & & -0.6 & -0.6 & & & -0 . & 0.286 & -0.346 & -0.161 & -0 . & -0.48 \\
\hline ther Cereals & -0.65 & 0.454 & -0.182 & -0.62 & -0.768 & -0.807 & -0.291 & 2.354 & 0.404 & -0.178 & -0.524 & -0.65 \\
\hline
\end{tabular}

Table A4: Rural areas expenditure, compensated and uncompensated elasticity coefficients estimates

\begin{tabular}{lcccc}
\hline & & \multicolumn{2}{c}{ Price } & \\
& Imported Rice & Local Rice & Maize & Other Cereals \\
\hline Budget Elasticities & 1.1782 & 0.7405 & 0.9507 & 1.1379 \\
& $(0.0145)$ & $(0.0156)$ & $(0.0396)$ & $(0.0175)$ \\
Compensated Elasticity & & & & \\
Imported Rice & -0.2560 & 0.0683 & 0.0535 & 0.1342 \\
& $(0.0130)$ & $(0.0106)$ & $(0.0068)$ & $(0.0103)$ \\
L Local Rice & 0.0774 & -0.2138 & 0.0371 & 0.0994 \\
\hline
\end{tabular}




\begin{tabular}{|c|c|c|c|c|c|}
\hline \multirow{2}{*}{\multicolumn{2}{|c|}{ Maize }} & $(0.0113)$ & $(0.0189)$ & $(0.0076)$ & $(0.0111)$ \\
\hline & & 0.2310 & 0.1719 & -0.4352 & 0.0323 \\
\hline \multirow{3}{*}{\multicolumn{2}{|c|}{ Other Cereals }} & $(0.0297)$ & $(0.0333)$ & $(0.0341)$ & $(0.0263)$ \\
\hline & & 0.2393 & 0.1702 & 0.0150 & -0.4244 \\
\hline & & $(0.0181)$ & $(0.0190)$ & $(0.0105)$ & $(0.0275)$ \\
\hline \multicolumn{6}{|c|}{ Uncompensated Elasticity } \\
\hline \multirow{8}{*}{ 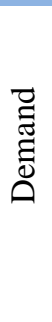 } & \multirow[t]{2}{*}{ Imported Rice } & -0.690 & -0.339 & -0.043 & -0.106 \\
\hline & & $(0.015)$ & $(0.011)$ & $(0.007)$ & $(0.011)$ \\
\hline & \multirow[t]{2}{*}{ Local Rice } & -0.196 & -0.470 & -0.023 & -0.051 \\
\hline & & $(0.013)$ & $(0.021)$ & $(0.008)$ & $(0.010)$ \\
\hline & \multirow[t]{2}{*}{ Maize } & -0.120 & -0.157 & -0.513 & -0.161 \\
\hline & & $(0.032)$ & $(0.033)$ & $(0.035)$ & $(0.027)$ \\
\hline & \multirow[t]{2}{*}{ Other Cereals } & -0.180 & -0.223 & -0.078 & -0.656 \\
\hline & & $(0.020)$ & $(0.019)$ & $(0.011)$ & $(0.028)$ \\
\hline
\end{tabular}

Standard errors in parenthesis

Note: This table reports the budget, compensated and uncompensated elasticities for imported rice, local, maize and other cereals' demand among Nigerian rural households

Table A5: Urban areas expenditure, compensated and uncompensated elasticity coefficients estimates

\begin{tabular}{|c|c|c|c|c|c|}
\hline & \multicolumn{4}{|c|}{ Price } \\
\hline & & Imported Rice & Local Rice & Maize & Other Cereals \\
\hline \multicolumn{2}{|c|}{ Budget Elasticities } & $\begin{array}{c}1.093 \\
(0.008)\end{array}$ & $\begin{array}{c}0.515 \\
(0.031)\end{array}$ & $\begin{array}{c}0.885 \\
(0.062)\end{array}$ & $\begin{array}{c}1.384 \\
(0.044)\end{array}$ \\
\hline \multicolumn{6}{|c|}{ Compensated Elasticity } \\
\hline \multirow{6}{*}{$\begin{array}{l}\widetilde{\Xi} \\
\text { ప్ర } \\
\text { ص. }\end{array}$} & Imported Rice & $\begin{array}{l}-0.113 \\
(0.008)\end{array}$ & $\begin{array}{c}0.013 \\
(0.006)\end{array}$ & $\begin{array}{c}0.047 \\
(0.004)\end{array}$ & $\begin{array}{c}0.053 \\
(0.006)\end{array}$ \\
\hline & Local Rice & $\begin{array}{c}0.054 \\
(0.022)\end{array}$ & $\begin{array}{l}-0.020 \\
(0.027)\end{array}$ & $\begin{array}{l}-0.010 \\
(0.012)\end{array}$ & $\begin{array}{l}-0.024 \\
(0.016)\end{array}$ \\
\hline & Maize & 0.613 & -0.019 & -0.267 & -0.327 \\
\hline & & $(0.055)$ & $(0.045)$ & $(0.051)$ & $(0.041)$ \\
\hline & Other Cereals & 0.424 & -0.050 & -0.199 & -0.175 \\
\hline & & $(0.047)$ & $(0.037)$ & $(0.025)$ & $(0.065)$ \\
\hline \multicolumn{6}{|c|}{ Uncompensated Elasticity } \\
\hline \multirow{8}{*}{ 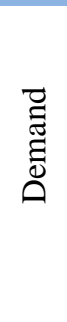 } & Imported Rice & -0.857 & -0.189 & -0.009 & -0.038 \\
\hline & & $(0.011)$ & $(0.006)$ & $(0.004)$ & $(0.006)$ \\
\hline & Local Rice & -0.296 & -0.115 & -0.036 & -0.067 \\
\hline & & $(0.032)$ & $(0.027)$ & $(0.012)$ & $(0.016)$ \\
\hline & Maize & 0.011 & -0.183 & -0.313 & -0.401 \\
\hline & & $(0.061)$ & $(0.043)$ & $(0.052)$ & $(0.042)$ \\
\hline & Other Cereals & -0.517 & -0.306 & -0.270 & -0.291 \\
\hline & & $(0.054)$ & $(0.035)$ & $(0.026)$ & $(0.066)$ \\
\hline
\end{tabular}

Standard errors in parenthesis

Note: This table reports the budget, compensated and uncompensated elasticities for imported rice, local, maize and other cereals' demand among Nigerian urban households 